\title{
Studi Literatur Perencanaan Floating Treatment Wetland di Indonesia
}

\author{
Laella Pusparinda dan R. Irwan Bagyo Santoso \\ Jurusan Teknik Lingkungan, Fakultas Teknik Sipil dan Perencanaan, Institut Teknologi Sepuluh Nopember (ITS) \\ Jl. Arief Rahman Hakim, Surabaya 60111 Indonesia \\ e-mail:irwan080565@gmail.com
}

\begin{abstract}
Abstrak-Floating Treatment Wetland (FTW) merupakan salah satu jenis constructed wetland yang ditanam dalam media yang dapat mengapung dipermukaan air. Dalam FTW tanaman tidak ditanam di tanah melainkan pada media apung yang kemudian diletakkan di permukaan air. Akar tanaman menggantung di badan air sebagai tempat tumbuhnya biofilm dan juga menyaring partikulat tersuspensi. FTW telah diaplikasikan di berbagai negara di dunia namun belum di Indonesia. Studi literatur ini bertujuan untuk meninjau dan menginterpretasikan informasi yang relevan untuk pengembangan dan penerapan FTW di negara tropis. Yaitu dengan merangkum berbagai percobaan yang telah dilakukan untuk lebih memahami kemampuan FTW dalam mereduksi kontaminan dan mengidentifikasi kriteria desain perencanaan FTW. FTW terdiri dari tanaman emergent plant, media tanam, media apung (bouyant material dan bouyant frame), dan anchor. Pemilihan tanaman adalah berdasarkan ketersediaan tanaman (tanaman lokal) yang mampu tumbuh secara optimal dengan kondisi lingkungan dan iklim Indonesia. FTW menggunakan sistem apung sehingga dapat secara langsung diaplikasikan di badan air. Sistem anchoring berfungsi untuk menahan FTW dari pengaruh arus, angin, gelombang, dan fluktuasi ketinggian air. Kriteria desain perencanaan FTW adalah kedalaman air $>0,8 \mathrm{~m}$, HRT $<15$ hari, surface coverage $5 \%-50 \%$, dan HLR 0,1-0,3 $\mathrm{m}^{3} / \mathrm{m}^{2}$.hari.
\end{abstract}

Kata Kunci-constructed wetland, floating treatment wetland, kriteria desain, sistem apung, tanaman

\section{PENDAHULUAN}

C ONSTRUCTED wetland atau lahan basah buatan merupakan salah satu teknologi pengolahan air limbah. Seluruh bagian kehidupan manusia secara langsung maupun tidak langsung selalu terkait dengan keberadaan lahan basah. Mulai dari penyedia air minum, habitat berbagai jenis makhluk, penyedia bahan pangan, pengendali banjir, sampai penjaga kondisi iklim global. Proses penjernihan air di constructed wetland dilakukan secara biologis dengan bantuan mikroorganisme, proses fisika, dan proses kimia [1].

FTW merupakan salah satu jenis constructed wetland. Umumnya constructed wetland menggunakan media tanam untuk mendukung perakaran tumbuhan ataupun menggunakan tumbuhan submergent aquatic yang dapat mengapung dipermukaan air. Sedangkan FTW, menggunakan emergent plants yang ditanam dalam suatu media yang mengapung, sehingga akar dapat menggantung bebas didalam air sedangkan daun muncul diatas permukaan air [2].

FTW digunakan untuk meningkatkan kualitas air, pengolahan air limbah domestik, pengolahan sungai, kolam, danau, dan reservoir, serta pengolahan limbah industri [3]. FTW telah diaplikasikan di berbagai negara di dunia namun belum di Indonesia. FTW sesuai diaplikasikan di negara dengan iklim tropis karena tidak memiliki musim dingin sehingga tumbuhan dapat hidup sepanjang tahun [2]. Berdasarkan fakta tersebut, maka perlu dilakukan studi literatur FTW untuk mengetahui kriteria desain dan kemungkinan hasil studi untuk diaplikasikan di Indonesia.

\section{METODE STUDI}

\section{A. Penentuan Judul Studi}

Ide studi didapatkan dengan melakukan gap analysis untuk membandingkan kondisi di lapangan dengan kondisi yang ideal. Ide studi berasal dari belum diapliaksikannya FTW di Indonesia padahal berpotensi untuk meningkatkan kualitas air yang tercemar. Sehingga penulis membuat judul "Studi Literatur Perencanaan Floating Treatment Wetland di Indonesia".

\section{B. Studi Literatur}

Studi literatur bertujuan untuk mendukung dan meningkatkan pemahaman terhadap ide penelitian. Sumber literatur yang digunakan adalah jurnal internasional, jurnal Indonesia, dan text book yang berhubungan dengan topik yang dibahas. Studi literatur dikelompokkan menjadi beberapa bagian yaitu: teori constructed wetland, fitoproses dalam tumbuhan, hukum Archimedes, sistem hidroponik, teori FTW, faktor yang mempengaruhi FTW, studi kasus pengaplikasian FTW, struktur pembuatan FTW, list tanaman, dan sistem anchoring.

\section{Analisis Data}

Hasil dan pembahasan mendeskripsikan beberapa hal sebagai berikut:

- Struktur FTW

Dari studi kasus kemudian dihubungkan dengan studi literatur hukum Archimedes, struktur pembuatan FTW, list tanaman, dan sistem anchoring, sehingga dapat diketahui tanaman, media tanam, media apung, dan sistem anchoring yang sesuai untuk FTW.

- Parameter Desain FTW

Dari studi kasus kemudian dihubungkan dengan studi literatur teori constructed wetland, teori FTW, dan faktor yang mempengaruhi FTW sehingga dapat diketahui kriteria desain perencanaan FTW. 


\section{- Pengelolaan FTW}

Dari studi kasus kemudian dihubungkan dengan studi literatur sistem hidroponik, fitoproses, dan aplikasi FTW dapat diketahui pengelolaan yang sesuai untuk FTW.

\section{HASIL DAN PEMBAHASAN}

\section{A. Mekanisme Pengolahan FTW}

FTW merupakan sistem pengolahan yang tergolong baru [4]. FTW telah diaplikasikan di berbagai negara untuk meningkatkan kualitas air dengan spesies tanaman dan keadaan lingkungan yang berbeda [13]. Biofilm yang terbentuk pada akar merupakan area yang luas untuk pengolahan [20].

Bagian utama dari FTW adalah media yang dibuat mengapung (Gambar 1). FTW telah digunakan untuk meremediasi berbagai limbah perkotaan [5], pertanian [6], dan industri [7]. FTW terbukti mampu mereduksi BOD, nutrien, dan kandungan solid dalam air limbah. Selain itu juga telah digunakan untuk meremediasi logam berat seperti $\mathrm{Cd}, \mathrm{Cr}, \mathrm{Fe}$, $\mathrm{Pb}, \mathrm{Mn}, \mathrm{Se}, \mathrm{Zn}$, dan zat organik beracun lainnya dalam air limbah [2]. Kelebihan dari FTW adalah tidak terpengaruh pada fluktuasi air dan tidak membutuhkan banyak lahan karena dapat diaplikasikan langsung di badan air [8].

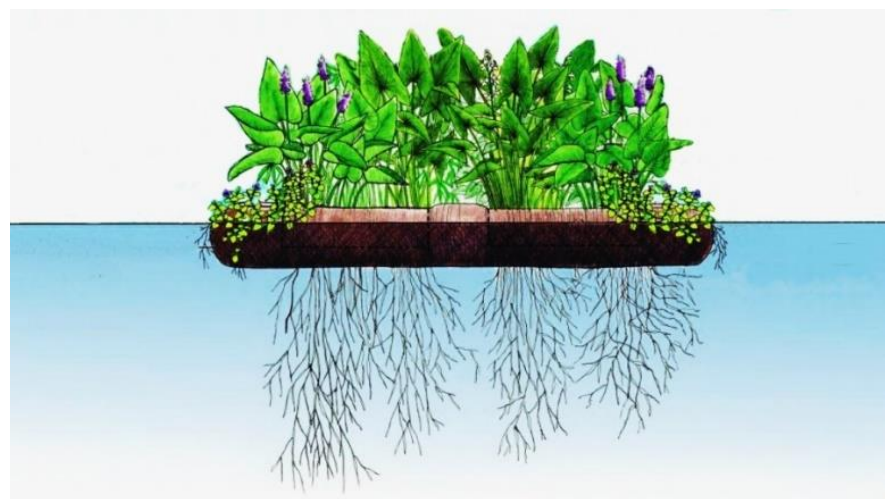

Gambar 1. Skema Floating Treatment Wetland

Selain memperbaiki kualitas air, FTW juga memberikan manfaat lain yaitu memberikan habitat baru bagi hewan, melindungi daerah pesisir, dan menambah estetika lingkungan. Ketika FTW dibangun di daerah pesisir maka dapat mereduksi ombak, mencegah erosi, dan sebagai habitat bagi satwa liar [9] - [10]. Jika dibandingkan dengan lahan basah (constructed wetland) lainnya, FTW memiliki kesamaan dan perbedaan yang dapat dilihat pada Tabel 1.

Tabel 1.

Kesamaan dan Perbedaan FTW

\begin{tabular}{cll}
\hline \hline Teknologi & \multicolumn{1}{c}{ Kesamaan } & \multicolumn{1}{c}{ Perbedaan } \\
\hline \multirow{3}{*}{ Kolam } & FTW adalah kolam & Kolam didominasi oleh \\
& dengan tanaman yang & fitoplankton, tidak ada \\
& ditanam pada media & tanaman, dan permukaan \\
& yang mengapung. & airnya tidak tertutup. \\
& Tanaman yang & Aliran air SFW berada di \\
\multirow{5}{*}{ Surface flow } & digunakan adalah & zona batang bukan di zona \\
& emergent macrophyte. & akar seperti FTW. Tanaman \\
& Tidak menggunakan & SFW berakar dan \\
& gravel atau media & mengambil nutrien dari \\
\hline \hline
\end{tabular}

\begin{tabular}{cll}
\hline \hline Teknologi & \multicolumn{1}{c}{ Kesamaan } & \multicolumn{1}{c}{ Perbedaan } \\
\hline & lainnya. & $\begin{array}{l}\text { tanah sedangkan tanaman } \\
\text { FTW mengambil nutrien } \\
\text { dari air (sistem hidroponik). }\end{array}$ \\
Horizontal & Aliran air dan & FTW tidak menggunakan \\
subsurface & pengolahan terjadi di & media gravel atau lainnya. \\
flow wetland & zona akar tanaman. & FTW terdiri dari tanaman \\
& Tanaman berada di & emergent macrophyte yang \\
permukaan air dengan & ditanam pada media apung. \\
macrophyte & badan air. & FTW mempunyai sistem \\
wetland & & $\begin{array}{l}\text { anchoring sehingga tidak } \\
\text { terpengaruh pada angin } \\
\text { maupun aliran air. }\end{array}$ \\
\hline \hline
\end{tabular}

Tanaman dan mikroorganisme yang tumbuh di akar memiliki peran penting dalam proses pengolahan FTW. Pengolahan polutan (Tabel 2) terjadi secara fisik, biologi, dan kimia [11] [12].

Tabel 2

Mekanisme Pengolahan FTW

\begin{tabular}{|c|c|}
\hline Polutan & Mekanisme Pengolahan \\
\hline Padatan tersuspensi & $\begin{array}{l}\text { - Sedimentasi } \\
\text { - Filtrasi }\end{array}$ \\
\hline Organik terlarut & $\begin{array}{l}\text { - Biodegradasi secara aerobik } \\
\text { - Biodegradasi secara anaerobik }\end{array}$ \\
\hline Fosfor & $\begin{array}{l}\text { - Plant uptake } \\
\text { - Adsorpsi media tanam }\end{array}$ \\
\hline Nitrogen & $\begin{array}{l}\text { - Nitrifikasi } \\
\text { - Denitrifikasi } \\
\text { - Plant uptake } \\
\text { - Adsorpsi media tanam } \\
\text { - Volatilisasi }\end{array}$ \\
\hline Zat besi & $\begin{array}{l}\text { - Adsorpsi dan pertukaran ion } \\
\text { - Presipitasi } \\
\text { - Plant uptake } \\
\text { - Oksidasi atau reduksi oleh } \\
\text { mikroorganisme }\end{array}$ \\
\hline Pathogens & $\begin{array}{l}\text { - Sedimentasi } \\
\text { - Filtrasi } \\
\text { - Natural die - off } \\
\text { - Predator } \\
\text { - UV irradiation } \\
\end{array}$ \\
\hline
\end{tabular}

\section{B. Struktur Floating Treatment Wetland}

Secara umum FTW terdiri dari tanaman, media tanam, media apung (bouyant material dan bouyant frame), dan sistem anchoring, sebagai berikut:

i) Tanaman

FTW menggunakan sistem hidroponik [13]. Berbagai jenis tanaman telah diaplikasikan untuk pengolahan dengan FTW. Pemilihan spesies adalah berdasarkan ketersediaan tanaman (tanaman lokal) yang dapat tumbuh maksimal dengan kondisi lingkungan dan iklim tropis. Selain itu juga harus diperhatikan akar tanaman dan pertumbuhan tanaman. Tanaman yang mempunyai pertumbuhan tinggi cenderung memiliki hambatan angin yang lebih besar sehingga membutuhkan sistem penambatan (anchoring) yang lebih kuat. Tanaman yang sering digunakan dalam sistem FTW adalah jenis tanaman Canna, Carex, Cyperus, Juncus, Phragmites, dan Typha [13]. Berdasarkan prinsip hidroponik, ketersediaan tanaman, dan 
keberhasilan tanaman untuk mereduksi polutan maka dapat diketahui beberapa jenis tanaman lokal yang berpotensi untuk pengolahan FTW di Indonesia, yaitu:

- Acorus calamus (Karumenga)

- Acorus gramineus (Jeringau)

- Agapanthus africanus (Bunga agapanthus biru)

- Alternanthera philoxeroides (Bayam dempo)

- Anthurium andraeanum (Bunga kuping gajah)

- Calla palustris (Calla)

- Canna flaccida (Bunga tasbih kuning)

- Canna generalis (Bunga tasbih oranye)

- Canna indica (Bunga tasbih merah)

- Carex sp. (Rumput sianik)

- Carthamus tinctorius (Kesumba)

- Coix lacryma-jobi (Jali)

- Colocasia esculenta (Talas)

- Crotalaria juncea (Orok-orok)

- Cynodon dactylan (Rumput grinting)

- Cyperus haspans (Rumput payung)

- Cyperus involucratus (Papirus payung)

- Cyperus papyrus (Papirus)

- Cyperus ustulatus (Rumput teki)

- Eleocharis dulcis (Purun tikus)

- Glyceria maxima (Ilalang air)

- Hedychium conronarium (Gandasuli)

- Hibiscus moscheutos (Bunga sepatu)

- Iris pseudacorus (Iris kuning)

- Ipomoea aquatica (Kangkung air)

- Juncus effusus (Tapak dara air)

- Lythrum salicaria (Rumput cengeng)

- Matthiola incana (Bunga Matthiola)

- Mentha aquatica (Mint air)

- Myosotis palustris (Bunga dianthus)

- Pancium repens (Rumput lampuyangan)

- Peltandra virginica (Keladi)

- Phragmites karka (Perumpung)

- Polygonum barbatum (Mengkrengan)

- Pontederia cordata (Pandan air)

- Saggitaria latifolia (Lili air)

- Sagittaria lancifolia (Daun tombak)

- Saururus cernuus (Bunga ekor cicak)

- Schoenoplectus tabernaemontani (Bambu air)

- Spartina pectinata (Rumput prairie cordgrass)

- Strelitzia reginae (Bunga burung surga)

- Thalia dealbata (Kana air)

- Typha angustifolia (Lembang)

- Typha latifolia (Purun)

- Zantedeschia aethiopica (Kala lili)

- Zizania latifolia (Padi liar)

\section{ii) Media Tanam}

Prinsip apung FTW adalah hukum Archimedes. Ada dua pendekatan yang dapat dilakukan agar FTW mengapung, yaitu dengan penggunaan media tanam apung (bouyant material) atau penggunaan bingkai apung (bouyant frame) [14]. Contoh dari bouyant material adalah matrik Biohaven dan matrik Beemats, yang belum ada di Indonesia. Karena itu penggunaan bingkai apung (bouyant frame), seperti pipa PVC ataupun bambu, akan lebih efektif di Indonesia. Selain tanah, ada beberapa media tanam hidroponik yang dapat diaplikasikan untuk FTW, antara lain arang sekam, cocopeat, dan rockwoll. Persyaratan terpenting untuk media tanam FTW adalah harus ringan dan porus sehingga mampu melarutkan nutrisi dengan baik. Jarak antar tanaman perlu diperhatikan. Berbagai penelitian telah dilakukan dengan desain yang berbeda. Bouyant material produksi Biohaven memiliki jarak $15 \mathrm{~cm}$ diantara lubang tanaman. Sedangkan produk dari Beemats memiliki jarak $30 \mathrm{~cm}$. Rujukan [15] menanam Schoenoplectus tabernaemontani pada bouyant frame (PVC dan Net), dengan jarak antar tanaman adalah $10 \mathrm{~cm}$. Dan tanaman tersebut tumbuh dengan baik selama masa studi. Jarak tanam yang ideal adalah berdasarkan morfologi tanaman dan kebutuhan sinar matahari. Semakin lebar tajuk, penyebaran akar, dan kebutuhan sinar matahari suatu tanaman maka diperlukan jarak tanam yang semakin lebar pula.

iii) Sistem Anchoring

Anchor berfungsi untuk menahan FTW dari pengaruh arus, angin, gelombang, dan fluktuasi ketinggian air, sehingga FTW tidak bergerak dari tempatnya [16]. Beberapa hal yang perlu diperhatikan dalam pemasangan anchor adalah berat, jumlah, letak, dan panjang tali anchor. Anchor dapat terbuat dari besi, beton, atau kayu keras yang dibuat seperti jangkar besi yang dipakai di kapal. Sistem anchoring terbagi menjadi dua yaitu sistem pemberat dan sistem tali. Sistem pemberat digunakan untuk FTW yang diaplikasikan di tengah badan air. Sedangkan sistem tali digunakan untuk FTW yang diaplikasikan ditepi badan air. Tali anchor yang digunakan berupa plastik atau polythylene berdiameter $3-5 \mathrm{~cm}$, dengan panjang tali anchor tiga kali kedalaman badan air. Untuk mengetahui berat anchor yang diperlukan, maka dihitung gaya (external force) yang bekerja pada anchor sebagai berikut:

$$
\begin{aligned}
F=\frac{\rho \times C d \times A \times\left(\mathrm{v}_{1}{ }^{2}+\mathrm{v}_{2}{ }^{1}+\mathrm{v}_{3}{ }^{2}\right)}{\text { Keterangan: } F} & =\text { gaya angin }(\mathrm{N}) \\
\rho & =\text { densitas udara }\left(\mathrm{kg} / \mathrm{m}^{3}\right) \\
C d & =\text { koefisien drag } \\
A & =\text { luas FTW }\left(\mathrm{m}^{2}\right) \\
v_{1} & =\text { kecepatan angin }(\mathrm{m} / \mathrm{s}) \\
v_{2} & =\text { kecepatan arus air }(\mathrm{m} / \mathrm{s}) \\
v_{3} & =\text { kecepatan gelombang }(\mathrm{m} / \mathrm{s})
\end{aligned}
$$

Dengan diketahuinya gaya total yang bekerja pada FTW, maka dapat dihitung berat jangkar yang diperlukan. Berat sebuah benda adalah gaya gravitasi yang diberikan pada benda tersebut. Kalimat tersebut didefinisikan dalam persamaan $\mathbf{w}=$ $\mathbf{m} \mathbf{x}$ g. Karena berat adalah sebuah gaya, ilmuwan juga menuliskan:

$F=m \times g$

$\begin{array}{ll}\text { Keterangan: } & \mathrm{F}=\text { gaya total FTW }(\mathrm{N}) \\ & \mathrm{m}=\text { massa jangkar }(\mathrm{kg}) \\ \mathrm{g} & =\text { percepatan gravitasi }\left(\mathrm{m} / \mathrm{s}^{2}\right)\end{array}$ 


\section{ParameterDesain Floating Treatment Wetland}

Beberapa parameter desain untuk perencanaan FTW adalah kedalaman badan air, waktu detensi, dan luas permukaan badan air yang tertutupi oleh FTW (surface coverage), sebagai berikut:

i) Kedalaman Air

Kedalaman air dalam sistem FTW ditentukan berdasarkan panjang maksimal akar dari tanaman yang digunakan. Dari berbagai penelitian [17]-[18]-[19]-[20] dibuatlah grafik (Gambar 2) yang menunjukkan bahwa efisiensi pengolahan sebanding dengan kedalaman badan air. Rujukan [2] merekomendasikan kedalaman air minimal untuk FTW adalah 0,8 m. Hal ini bertujuan agar akar tanaman tidak sampai pada zona bawah. Jika akar mencapai zona bawah maka akar akan menempel dan mulai berakar di tanah ataupun sedimen yang mengendap. Jika hal tersebut terjadi, dikhawatirkan saat terjadi fluktuasi air maka FTW akan tertarik ke bawah dan tenggelam.

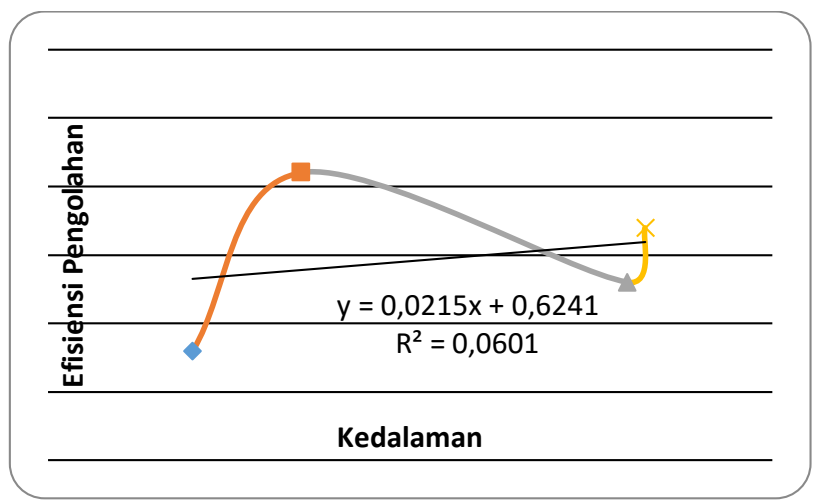

Gambar 2. Pengaruh Kedalaman Air terhadap Efisiensi Pengolahan TN

\section{ii) HRT (Hydraulic Retention Time)}

Waktu kontak antara limbah dengan FTW perlu dimaksimalkan untuk mendapat hasil pengolahan yang optimal [21]. Jika HRT tinggi maka akan memperbesar luas FTW. Namun hal ini dapat diatasi dengan memperdalam badan air karena FTW tidak terpengaruh pada fluktuasi air. Hasil penelitian [22] menunjukkan bahwa semakin tinggi nilai HRT maka didapatkan hasil pengolahan TP yang semakin, namun tidak pada TN. Pada HRT 15 hari keatas terlihat tidak adanya penambahan efisiensi pengolahan yang signifikan. Misalkan saja pada pengolahan TP dengan HRT 27 hari didapatkan efiisensi pengolahan sebesar 92,6\% dan pada HRT 37 hari didapatkan 94,4\%. Sedangkan pada pengolahan TN dengan HRT 27 hari didapatkan efisiensi pengolahan sebesar 75,6\% dan pada HRT 37 hari mengalami penurunan menjadi $70,9 \%$. Berdasarkan hal tersebut maka [18] merekomendasikan HRT maksimal untuk FTW adalah 15 hari.

\section{iii) Surface Coverage}

Tertutupinya permukaan air oleh FTW akan mengurangi jumlah cahaya yang masuk ke dalam air. Hal tersebut dapat berpengaruh pada berkurangnya jumlah alga dan mencegah terjadinya algae bloom [23]-[24]. Namun, surface coverage juga mempengaruhi jumlah oksigen terlarut dalam air. Dari berbagai penelitian [17]-[18]-[19]-[20] dibuatlah grafik (Gambar 3) yang menunjukkan bahwa efisiensi pengolahan FTW mengalami penurunan pada surface coverage lebih dari $50 \%$.
Selain itu [25] juga menyebutkan bahwa surface coverage $5 \%$ sudah mampu mengolah nutrien yang signifikan dalam waktu (HRT) 15 hari dengan konsentrasi pencemar Fosfat $1 \mathrm{mg} / \mathrm{L}$ dan Nitrat $3 \mathrm{mg} / \mathrm{L}$. Surface coverage yang lebih besar dari 5\% dibutuhkan ketika HRT kurang dari 15 hari. Maka direkomendasikan surface coverage untuk FTW adalah antara 5-50\% karena jika terlalu tinggi dari angka tersebut dikhawatirkan akan menyebabkan kondisi anoxic pada badan air.

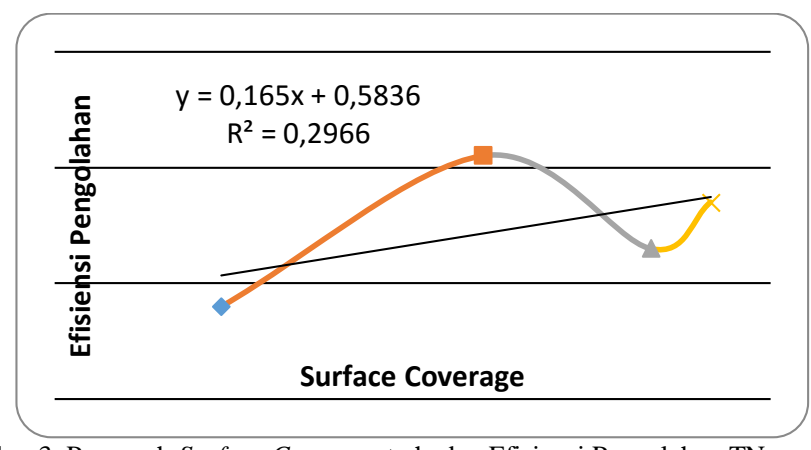

Gambar 3. Pengaruh Surface Coverage terhadap Efisiensi Pengolahan TN

iv) HLR (Hydraulic Loading Rate)

Belum ada penelitian lebih lanjut mengenai pengaruh HLR terhadap efisiensi pengolahan FTW. Berdasarkan data dari berbagai macam penelitian [17]-[18]-[20] yang telah dilakukan dibuatlah grafik pada Gambar 4. Dapat diketahui bahwa FTW memiliki efisiensi pengolahan yang baik pada HLR dalam rentang $0,1-0,3 \mathrm{~m}^{3} / \mathrm{m}^{2}$.hari.

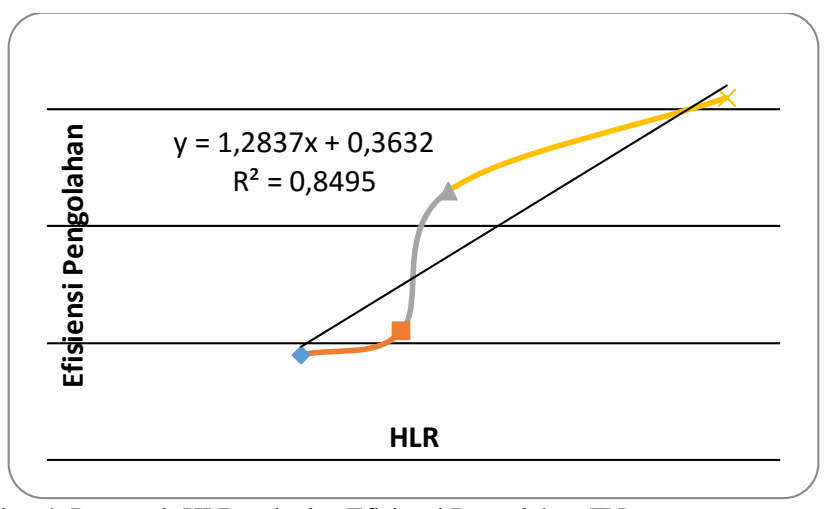

Gambar 4. Pengaruh HLR terhadap Efisiensi Pengolahan TN

\section{Pengelolaan Floating Treatment Wetland}

Prosedur pengelolaan umum yang dapat diterapkan untuk FTW antara lain:

1. Memastikan kekuatan tambatan (anchoring)

2. Memastikan sambungan antara media tanam dan media apung.

3. Pemanenan dilakukan untuk tanaman yang telah berada pada siklus akhir hidupnya yaitu ketika tanaman telah tua dan mulai berguguran. Cara panen yang digunakan adalah panen keseluruhan atau panen sebagian. Panen keseluruhan berarti memanen tanamn dengan cara mencabut hingga akarnya. Sedangkan panen sebagian adalah dengan memotong tumbuhan yang telah dewasa (indukan) dan meninggalkan tumbuhan yang masih muda (anakan) sehingga jumlah tumbuhan tidak terlalu padat. 
Tanaman yang telah dipanen dapat dijadikan kompos atau pakan hewan. Pemanenan tanaman dilakukan pada seluruh bagian tanaman untuk mencegah kembalinya kontaminan ke badan air [10]. Waktu pemanenan adalah berdasarkan masa hidup masing-masing spesies.

4. Memastikan endapan yang terbentuk di dasar badan air setiap 1 bulan sekali dan melakukan pengerukan apabila telah terbentuk banyak sedimen agar zat-zat yang telah mengendap tidak kembali ke lingkungan.

5. Lakukan pengambilan sampel air setiap 1 bulan sekali untuk mengetahui kualitas efluen dari FTW.

6. Pemilihan umur tanaman untuk tahap awal pembuatan FTW perlu diperhatikan. Tanaman yang terlalu muda berpotensi mengalami kerusakan oleh serangan burung ataupun hewan lainnya. Hal ini akan memberikan dampak buruk pada FTW karena salah satu manfaat FTW adalah untuk memberikan habitat bagi satwa liar. Untuk menjamin kehidupan tanaman pada tahap awal dapat digunakan tanaman yang kuat (Phragmites, Cyperus spp.), tanaman yang runcing (Juncus, Schoenoplectus spp.), atau tanaman yang mempunyai daun yang tajam (Carex spp.). Cara lainnya yang dapat dilakukan adalah dengan melakukan pembibitan tanaman sebelum dipindah ke badan air [13].

\section{KESIMPULAN/RINGKASAN}

FTW terdiri dari tanaman emergent plant, media tanam, media apung (bouyant material dan bouyant frame), dan sistem anchoring. Pemilihan tanaman adalah berdasarkan ketersediaan tanaman (tanaman lokal) yang mampu tumbuh secara optimal dengan kondisi lingkungan dan iklim di Indonesia. Jarak tanam yang ideal adalah berdasarkan morfologi tanaman dan kebutuhan tanaman akan sinar matahari. Semakin lebar tajuk suatu tanaman dan penyebaran akar diperlukan jarak tanam yang semakin lebar pula. Jika kebutuhan tanaman akan sinar matahari semakin banyak maka dibutuhkan jarak tanam yang semakin lebar. FTW menggunakan sistem apung sehingga dapat secara langsung diaplikasikan di badan air. Sistem anchoring berfungsi untuk menahan FTW dari pengaruh arus, angin, gelombang, dan fluktuasi ketinggian air. Kriteria desain perencanaan FTW adalah kedalaman air $>0,8 \mathrm{~m}$, HRT $<15$ hari, surface coverage adalah 5\%-50\%, dan HLR adalah 0,1-0,3 $\mathrm{m}^{3} / \mathrm{m}^{2}$.hari.

\section{UCAPAN TERIMA KASIH}

Ucapan terimakasih penulis tujukan kepada segenap pihak di Jurusan Teknik Lingkungan FTSP ITS, atas bantuan dan dukungan dalam penyelesaian studi literatur perencanaan ini.

\section{DAFTAR PUSTAKA}

[1] Brix, H. 2005. The Use of Vertical Flow Constructed Wetlands for OnSite Treatment of Domestic Waste Water: New Danish Guidelines. Ecological Engineering 25, 491-500.

[2] Chua, L.H.C., S.B.K. Tan, C.H. Sim, dan M.K Goyal. 2012. Treatment of Baseflow From an Urban Catchment by a Floating Wetland System. Ecological Engineering 49, 170-180.

[3] Yeh, Naichia., Pulin Yeh, dan Yuan-Hsiou Chang. 2015. Artificialfloating Islands for Environmental Improvement. Renewable and Sustainable Energy Reviews 47, 616-622.
[4] Wang, Chih Yu., dan David J. Sample. 2014. Assessment of The Nutrient Removal Effectiveness of Floating Treatment Wetlands Applied to Urban Retention Ponds. Journal of Environmental Management 137: 23-35.

[5] Bartucca, Maria Luce., Tanja Mimmo, Stefano Cesco, dan Daniele Del Buono. 2016. Nitrate Removal from Polluted Water by Using a Vegetated floating System. Science of the Total Environment 542, 803808.

[6] Hubbard, RK., Anderson WF, Newton GL, Ruter JM, dan Wilson JP. 2011. Plant Growth and Elemental Uptake Byfloating Vegetation on A Single-Stage Swine Wastewater Lagoon. Trans Asabe 54, 837-45.

[7] Billore, SK., Prashant, dan Sharma JK. 2008. Treatment. Performance of Artificial Floating Reed Beds in an Experimental Mesocosm to Improve The Water Quality of River Kshipra. Water Science Technology 60, 2851-2859.

[8] Sample, David J., dan Chih Yu Wang. 2012. Design of Floating Treatment Wetlands for Water Quality Improvement. Department of Civil and Environmental Engineering Virgina Tech.

[9] Kamble, Rashmi., dan Dhawal Patil. 2012. Artificial Floating Island: Solution to River Water Pollution in India. Case Study: Rivers in Pune City. International Conference on Environmental, Biomedical and Biotechnology IPCBEE vol.41. Singapore: IACSIT Press.

[10] Li, Zhaohua., Yanqiang Li, Wei Huang, dan Lianhai Sang. 2013. Artificial Floating Islands: a Technology for Clean Water and Agricultural Production in Rural China. International Journal of Environmental Protection 3, 7-14.

[11] Kadlec, R. H., dan S. D. Wallace. 2009. Treatment Wetlands: Second Edition. Boca Raton: CRC Press.

[12] Sheoran, A.S., dan V. Sheoran. 2006. Heavy Metal Removal Mechanism of Acid Mine Drainage in Wetlands: A Critical Review. Minerals Engineering 19, 105-116.

[13] Headley, TR., dan C.C. Tanner. 2012. Constructed Wetlands with Floating Emergent Macrophytes: An Innovative Stormwater Treatment Technology. Environmental Science and Technology, 42, 2261-310.

[14] Kerr-Upal, M., M. Seasons, dan G. Mulamoottil. 2000. Retrofitting a Stormwater Management Facility with a Wetland Component. Journal of Environmental Science and health 8, 1289-1307.

[15] Wang, Chih Yu., dan David J. Sample. 2014. Assessment of The Nutrient Removal Effectiveness of Floating Treatment Wetlands Applied to Urban Retention Ponds. Journal of Environmental Management 137, 23-35.

[16] Zhen, Hu Xiao. 2002. Ecological Engineering Techniques for Lake Restoration In Japan. JICA: Ecological Engineering Purification System.

[17] Boonsong, K., dan M. Chansiri. 2008. Domestic Wastewater Treatment Using Vetiver Grass Cultivated with Floating Platform Technique. Journal of Technology, 12: 73-80.

[18] Li, X. N., H. L. Song, W. Li, X. W. Lu, dan O. Nishimura. 2010. An Integrated Ecological Floating-Bed Employing Plant, Freshwater Clam and Biofilm Carrier for Purification of Eutrophic Water. Ecological Engineering, 36: 382-390.

[19] Lu, Hsiao Ling., Chen Ruei Ku, dan Yuan Hsiou Chang. 2015. Water Quality Improvement with Artificial Floating Islands. Ecological Engineering, 74: 371-375.

[20] Sukias, J. P. S., J. Park, T. R. Headley, dan C. C. Tanner. 2011. Nutrient Removal from Eutrophic Waters by Floating Treatment Wetlands. Science of The Total Environment.

[21] Headley, TR., dan C.C. Tanner. 2006. Application of Floating Wetlands for Enhanced Stormwater Treatment. New Zealand: National Institute of Water \& Atmospheric Research Ltd.

[22] Chang, Ni-Bin., Zhemin Xuan, Zachary Marimon, Kamrul Islam, dan Martin P. Wanielista. 2013. Exploring Hydrobiogeo chemical Processes of Floating Treatment Wetlands in A Subtropical Stormwater Wet Detention Pond. Ecological Engineering 54, 66-76.

[23] Hubbard, R. K. 2010. Floating Vegetated Mats for Improving Surface Water Quality. Emerging Environmental Technologies 2, 211-244.

[24] Weragoda, S.K., K.B.S.N. Jinadasa, D.Q. Zhang, R.M. Gersberg, S.K. Tan, N. Tanaka, N.W. Jern. 2012. Tropical Application of Floating Treatment Wetlands. Wetlands 32, 955-961.

[25] White, Sarah A., dan Matthew M. Cousins. 2013. Floating Treatment Wetland Aided Remediation of Nitrogen AndPhosphorus from Simulated Stormwater Runoff. Ecological Engineering 61, 207-215. 